\title{
The Role of Theory Groups in the Lives of
}

\section{Ideas}

\section{Wendy Leeds-Hurwitz}

University of Wisconsin-Parkside, wendy.leeds.hurwitz@gmail.com

WE TEND to take for granted that good ideas are, and should be, accepted on their merits. However, it turns out that having a good idea, while certainly an essential beginning point, is no more than that. Ideas exist only insofar as they are put forward by people (who work in socially structured systems of recognition, reward, and power, of course), and so the people who invent, adopt, promote, or expand ideas turn out to be critically important to the study of the history of ideas. As I explained a few years ago, "Good ideas are not sufficient; neither self-generating nor self-sustaining, ideas do not arise de nova (from nowhere, out of nothing), and they rarely are accepted simply because someone recognized them as intrinsically valuable. ${ }^{11}$ But what else is required if good ideas are to be accepted? The short answer is that each idea needs at least two specific types of people, as well as some sort of "theory group" within which these people can share and promote the idea. In what follows, I will briefly summarize theory groups, and then mention a few implications.

Theory groups were initially outlined nearly fifty years ago by Belver C. Griffith and Nicholas C. Mullins, so they are not particularly new. ${ }^{2}$ Yet a quick search shows no one talking about theory groups in the major communication journals, and no relevant citations in the History of Communication Research Bibliography, so they require explanation if they are to attract the attention they deserve from communication researchers. ${ }^{3}$ Griffith and Mullins examined theory groups within sociology, emphasizing a series of developmental stages:
Wendy Leeds-Hurwitz, "The Role of Theory Groups in the Lives of Ideas," History of Media Studies 1 (2021), https://doi.org/10.32376/d895aoea.ob35e36e.

\section{c) (i) (5)}

${ }^{1}$ Wendy Leeds-Hurwitz, "The Emergence of Language and Social Interaction Research as a Specialty," in The Social History of Language and Social Interaction Research, ed. Wendy LeedsHurwitz (Cresskill: Hampton Press, 2010), 4 .

\footnotetext{
${ }^{2}$ Griffith and Mullins, "Coherent Social Groups in Scientific Change: 'Invisible Colleges' May Be Consistent Throughout Science," Science 177, no. 4053 (1972); Mullins, "The Development of a Scientific Specialty: The Phage Group and the Origins of Molecular Biology," Minerva 10 (1972); and Mullins, Theories and Theory Groups in Contemporary American Sociology (New York: Harper
} 
- Normal (intellectual leader appears)

- Network (organizational leader appears)

- Cluster (founders now have students, with 7-25 members in the central group)

- Specialty (textbook appears, work is recognized, with 20-100+ members)

Over the next few decades, Stephen O. Murray adapted and expanded that research, stressing what was needed for groups of people to share ideas, and for others to take them up, this time using anthropology as the discipline providing examples. ${ }^{4}$ My concern here will be with the value of theory groups for understanding the disciplinary history of communication, because I think we have too often ignored the role of theory groups in the lives of ideas.

A theory group is typically explained as a loose amalgam of individuals, held together by a shared theoretical orientation (rather than a group based at the same institution), requiring the leadership (both intellectual and organizational) of one or several individuals, with colleagues, students, or followers to carry their ideas forward. Ideas can only exist through continued attention, so the study of theory groups becomes the study of who invents and attends to particular ideas, sharing them with others, encouraging their development and expansion. Ideas can be promoted, shared, and become taken for granted; they can equally easily be ignored, forgotten, discredited, and thus disappear from communal memory. As Murray puts it, "The fate of ideas can be considered as depending on social processes rather than the intrinsic merit of the ideas." 5 Typically, scholars of communication, as in many other disciplines, emphasize ideas, often to the exclusion of the people who develop and discuss them. (Of course, this is not as true of historians of the field, who have often examined both people and contexts.) My argument here is that more of us need more often attend to the context of ideas-that is, the people surrounding and supporting them.

Assuming that Griffith and Mullins are correct, theory groups are essential to our study of ideas, and therefore should form part of any research into disciplinary history. Assuming Murray is correct, we must ask: What exactly needs to happen for an idea to be taken up by a group? To arrive at the answer, we need to understand how theory groups work generally, and also to study their function within specific disciplinary contexts. People develop ideas, and share them (or not), so it is impossible to study ideas without also considering the people who invent them and elaborate upon them (typically by teaching their students, discussing with colleagues or at conferences,
\& Row, 1973). "Invisible colleges" is an earlier and related term referring to a group of researchers who are not based at the same institution, yet who share research informally within the group, rather than only through more formal conference presentations and publications available to everyone. Diana Crane, Invisible Colleges: Diffusion of Knowledge in Scientific Communities (Chicago: University of Chicago Press, 1972). An example would be scholars who were graduate students together, and who still share informal descriptions of their research and findings with one another, despite having moved to different institutions, and having no obvious, public, visible connection. They are invisible because their connections will not be known to everyone, whereas colleagues working in the same department are more obviously visible as part of a single group. Invisible colleges are often most easily tracked through acknowledgments or overlapping lists of citations because members often review one another's drafts of research reports prior to publication. The concept of invisible colleges is useful, but need not concern us further here, given that it has already made it into the major communication journals, albeit not terribly frequently, but enough so it is clearly not a new concept. See also Randall Collins for another approach to what he terms "the social production of ideas," this time with a grand overview of world history. Like Crane, this is an approach which has already been noticed, at least to some extent, within communication, and so it does not require so much introduction to readers. Collins, The Sociology of Philosophies (Cambridge: Harvard University Press, 1998), chap. 15; and Collins, "The Sociology of Philosophies: A Precis," Philosophy of the Social Sciences 30, no. 2 (2000): 195. 3 See "History of Communication Research Bibliography," Annenberg School for Communication Library Archives, accessed September 14, 2021, https: //ascla.asc. upenn.edu/ communications-scholars-history-project/ bibliography/.

${ }^{4}$ Stephen O. Murray, Group Formation in Social Science (Edmonton: Linguistic Research, 1983); Murray, Theory Groups and the Study of Language in North America: A Social History (Amsterdam: John Benjamins, 1994); Murray, American Sociolinguistics: Theorists and Theory 
or publishing to reach a still larger group). Ideas have no independent existence-they cannot survive if people do not talk (and/or write) about them. But once they're shared with others, either orally or in written form, then they have a chance of spreading and being further developed. Of course, they can still be forgotten at any point if no one continues to write about them, read about them, and/or discuss them.

Murray examines in detail three factors, each necessary but insufficient for the formation of a theory group: (1) good ideas, (2) intellectual leadership, and (3) organizational leadership, across dozens of such groups (see Figure 1).

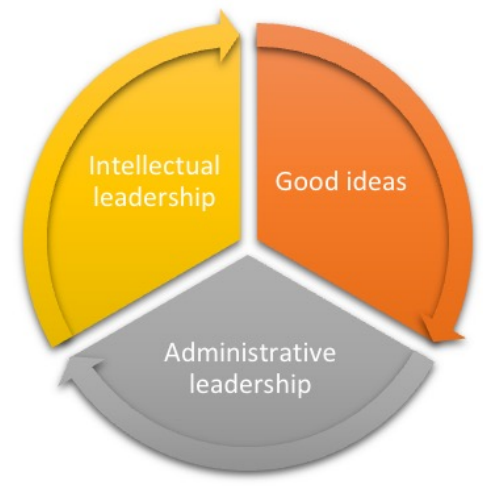

Figure 1: Relationship of Elements

Good ideas, even when paired with intellectual leadership, aren't enough; organizational leadership also turns out to be required. (The two types of leadership can be embodied by the same person, or not.) Murray's research demonstrates this by showing that a single recognized scholar writing up a good idea does not always result in that idea being adopted by others. ${ }^{6}$ Either that scholar or someone else must also be good at organization and thinking about the multiple steps needed beyond simply having a good idea: sharing that idea with students, organizing colloquia or conference presentations, writing up textbooks, and developing a new journal as an appropriate outlet, if one does not yet exist. Murray argues for the study of how ideas are communicated by and within groups, given that "changes in science are made by groups, not by the automatic breeding of ideas by other ideas, nor by single individuals, however brilliant their thoughts and research."7

Murray studies more elements than just the three named so far, including the difference between a rhetoric of continuity and a rhetoric of revolution (drawing on Kuhn), ${ }^{8}$ the difference between a claim to novelty and actual novelty, the impact of "eliteness" of the institutional context (Ivy League versus community college), and the
Groups (Amsterdam: John Benjamins, 1998); Murray, American Anthropology and Company: Historical Explorations (Lincoln: University of Nebraska Press, 2013); and Murray et al., "An Interview with Stephen O. Murray on Stephen O. Murray as Historian of Anthropology (and More)," in Centering the Margins of Anthropology's History, ed. Regna Darnell and Frederic W. Gleach (Lincoln: University of Nebraska Press, 2021)

5 Murray, Theory Groups and the Study of Language, 49.
${ }^{6}$ The issue is not necessarily a matter of holding a marginal position, or not getting recognition despite deserving it, but more the fact that there are two quite distinct criteria: being a successful intellectual leader, and being an effective strategic organizer for how, when, and where to ensure an idea is heard, accepted, and then applied and expanded upon.

${ }^{7}$ Murray, Group Formation in Social Science, 389.

\footnotetext{
${ }^{8}$ Thomas Kuhn, The Structure of Scientific Revolutions (Chicago: University of Chicago Press, 1962).
} 
relevance of generation (faculty vs. students). He shows that theory groups can have a single center (members being based at the same university) or be distributed geographically (as when students of the intellectual and/or organizational leader(s) move away to begin their own careers at various other universities). Similarly, monodisciplinary or interdisciplinary groups can both be successful, so long as the organizational leadership in an interdisciplinary group is particularly strong. This is required since advancement and prestige are typically determined within disciplines rather than across or between them.

What are the implications for accepting the essential role that theory groups occupy in shaping how ideas are developed and spread in disciplinary-history research? The central, and most obvious, implication is that those writing disciplinary history should attend explicitly to the theory groups putting forward new ideas, and not just focus on the development / expansion / revision of an original idea and its relationship to prior or later ideas. ${ }^{9}$ Once we recognize that ideas only exist through the people who discuss them, then we must expand the range of what we cover when we write the history of those ideas. A significant part of the task must be to sort out who originated the idea, who carried it forward, who presented it in what context, to what reception, etc. In short, we must pay attention to the part played by the people who gave life to the idea.

A second implication concerns the role of multidisciplinary or interdisciplinary research on academic careers. There is often a penalty for such projects, given that rewards typically occur within disciplines, so those who hold joint appointments or publish across disciplinary lines may, for example, not be given adequate recognition for publications in journals new to the committee considering promotion and tenure-even when this non-recognition is inadvertent. Perhaps it is time to break down the borders between disciplines altogether.

After all, they are merely fictions we have constructed, and so we should be deliberate about ignoring them when they prove a barrier to connections with others sharing overlapping interests, others who might become valuable members of our own present or future theory groups, spreading our ideas further than we can alone. ${ }^{10}$

A third implication relates to the potential fit between group communication research, especially intra-group communication, and theory groups. As a result, many communication scholars have directly relevant knowledge which might be applied to the task of understanding the communicative dynamics of theory groups beyond what scholars from other disciplines bring. This could help assure communication a seat at the table with other disciplinary historians (many of whom have been doing this for far longer than we have), given that
9 Some good examples specifically relevant to media studies can be found in David W. Park and Jefferson Pooley, eds., The History of Media and Communication Research: Contested Memories (New York: Peter Lang, 2008); Peter Simonson and David W. Park, eds., The International History of Communication Study (New York: Routledge, 2016); and Simonson et al., eds., The Handbook of Communication History (New York: Routledge, 2013). 
we would not just be studying our own history but sharing the ways in which our disciplinary lens might have value for everyone else.

Murray concludes, "These [theory] groups are vanguard parties, not representative of the whole population of working scientists. Over the course of their careers, most scientists are never involved in groups advancing new theoretical perspectives." 11 This should lead us to reconsider not only the ways in which we conduct research into disciplinary history, but also the ways in which we organize academia and even socialize future generations of academics. Would it not be beneficial for all if everyone had the opportunity to develop and work with ground-breaking, original ideas? ${ }^{12}$

\section{Bibliography}

Collins, Randall. The Sociology of Philosophies: A Global Theory of Intellectual Change. Cambridge: Harvard University Press, 1998.

Collins, Randall. "The Sociology of Philosophies: A Precis." Philosophy of the Social Sciences 30, no. 2 (2000): 157-201. https://doi.org/10. $1177 / 004839310003000201$.

Crane, Diana. Invisible Colleges: Diffusion of Knowledge in Scientific Communities. Chicago: University of Chicago Press, 1972.

Griffith, Belver C., and Nicholas C. Mullins. "Coherent Social Groups in Scientific Change: 'Invisible Colleges' May Be Consistent Throughout Science." Science 177, no. 4053 (1972): 959-64. https: //doi.org/10.1126/science.177.4053.959.

"History of Communication Research Bibliography." Annenberg School for Communication Library Archives. Accessed September 14, 2021. https: / / ascla.asc.upenn.edu/communicationsscholars-history-project/bibliography/.

Kuhn, Thomas. The Structure of Scientific Revolutions. Chicago: University of Chicago Press, 1962.

Leeds-Hurwitz, Wendy. "The Emergence of Language and Social Interaction Research as a Specialty." In The Social History of Language and Social Interaction Research: People, Places, Ideas, edited by Wendy Leeds-Hurwitz, 3-6o. Cresskill: Hampton Press, 2010.

Leeds-Hurwitz, Wendy. "These Fictions We Call Disciplines." Electronic Journal of Communication/La Revue Electronique de Communication 22, no. 3-4 (2012). http: //www. cios . org/EJCPUBLIC/022/ 3/022341. html.

Leeds-Hurwitz, Wendy, and Adam Kendon. "The Natural History of an Interview and the Microanalysis of Behavior in Social Interaction: A Critical Moment in Research Practice." In Holisms of Communication: The Early History of Audio-Visual Sequence Analysis, edited by James McElvenny and Andrea Ploder, 145-200. Berlin:
${ }^{11}$ Murray, Theory Groups and the Study of Language, 486.
${ }^{12}$ There is no space here to examine any theory group in detail. For one such example, see Wendy Leeds-Hurwitz and Adam Kendon, "The Natural History of an Interview and the Microanalysis of Behavior in Social Interaction: A Critical Moment in Research Practice," in Holisms of Communication: The Early History of Audio-Visual Sequence Analysis, ed. James McElvenny and Andrea Ploder (Berlin: Language Science Press, 2021), 145-200. 
Language Science Press, 2021.

Mullins, Nicholas C. "The Development of a Scientific Specialty: The Phage Group and the Origins of Molecular Biology." Minerva 10 (1972), 51-82. https://doi.org/10.1007/BF01881390.

Mullins, Nicholas C. Theories and Theory Groups in Contemporary American Sociology. New York: Harper \& Row, 1973.

Murray, Stephen O. Group Formation in Social Science. Edmonton: Linguistic Research, 1983.

Murray, Stephen O. Theory Groups and the Study of Language in North America: A Social History. Amsterdam: John Benjamins, 1994.

Murray, Stephen O. American Sociolinguistics: Theorists and Theory Groups. Amsterdam: John Benjamins, 1998.

Murray, Stephen O. American Anthropology and Company: Historical Explorations. Lincoln: University of Nebraska Press, 2013.

Murray, Stephen O., Wendy Leeds-Hurwitz, Regna Darnell, Nathan Dawthorne, and Robert Oppenheim. "An Interview with Stephen O. Murray on Stephen O. Murray as Historian of Anthropology (and More)." In Centering the Margins of Anthropology's History, edited by Regna Darnell and Frederic W. Gleach, 243-68. Lincoln: University of Nebraska Press, 2021.

Park, David W., and Jefferson Pooley, eds. The History of Media and Communication Research: Contested Memories. New York: Peter Lang, 2008.

Simonson, Peter, and David W. Park, eds. The International History of Communication Study. New York: Routledge, 2016.

Simonson, Peter, Janice Peck, Robert T. Craig, and John P. Jackson, Jr., eds. The Handbook of Communication History. New York: Routledge, 2013. 